\title{
COVID-19: Focus on masks and respirators - Implications for oral health-care workers
}

SADJ May 2020, Vol. 75 No. 4 p175 - p182

R Mulder ${ }^{1}$, N Layloo², S Mulder van Staden ${ }^{3}$

\section{INTRODUCTION}

The emergence of the novel human coronavirus (Severe acute respiratory syndrome coronavirus 2; abbreviated as: SARS-CoV-2) generally known as COVID-19 is a global health concern. ${ }^{1}$ On 11 February 2020, the World Health Organization $(\mathrm{WHO})$ named the novel viral pneumonia as "Corona Virus Disease" (COVID-19). The International Committee on Taxonomy of Viruses (ICTV) suggested this novel coronavirus be named "SARS-CoV-2" due to the phylogenetic and taxonomic analysis of this virus. ${ }^{2}$ Thus, both terms are utilised interchangeably in the literature.

Undoubtedly, COVID-19 will change the way we practice dentistry with vast implications for Oral health-care workers $(\mathrm{OHCW})$ and practice staff. Additionally, if rigorous safety protocols are not implemented based on a risk assessment outlined by the CDC, the dental practice can potentially become a nexus for disease transmission due to the high volume of aerosol production on a daily basis. Personal protective equipment (PPE), staff training and practice disinfection protocols have now especially become important in the light of the current pandemic.

This is not a fight that one profession can fight alone, it requires joint efforts, it requires all stakeholders, it requires foresight and it requires us to put the health of the communities above all else.

\section{ORAL HEALTH-CARE WORKERS (OHCW)}

OHCW face an overall elevated risk of exposure to various infectious diseases. ${ }^{3}$ The dental setting and wide range of procedures expose the $\mathrm{OHCW}$ via nume-

\section{Author affiliations:}

1. Riaan Mulder: $B C h D, M S c, P h D$, Senior Lecturer, Department of Restorative Dentistry, University of the Western Cape, Cape Town, South Africa.

ORCID Number: 0000-0002-8722-7632

2. Nazreen Layloo: $B C h D$, Lecturer, Department of Restorative Dentistry, University of the Western Cape, Cape Town, South Africa.

3. Suné Mulder van Staden: $B C h D, M C h D(O M P)$, Senior Lecturer, Department of Oral Medicine and Periodontics, University of the Western Cape, Cape Town, South Africa. ORCID Number: 0000-0003-3847-9451

Corresponding author: Riaan Mulder

Department of Restorative Dentistry, University of the Western Cape

Cape Town, South Africa.

Email: rmulder@uwc.ac.za

Author contributions:

1. Riaan Mulder: First author - 33\%

2. Nazreen Layloo: Second author - 33\%

3. Suné Mulder van Staden: Third author - 33\% rous pathways to pathogenic micro-organisms (such as viruses and bacteria) that infect the oral cavity and respiratory tract of a patient. ${ }^{1}$

\section{Potential routes of transmission of viruses include: ${ }^{4}$}

\section{Contact transmission:}

- Refers to infections from infected person to a susceptible individual through the transfer of virus-laden respiratory secretions. This transfer can be directly (via physical contact) or indirectly (via intermediate surfaces or objects).

\section{Droplet transmission:}

- Refers to infections transmitted by deposition of virus laden respiratory droplets expelled from an infected person onto mucosal surfaces (eyes, nose, mouth).

\section{Aerosol transmission:}

- Refers to infection via inhalation of virus laden fine respiratory droplets (aerosols) through the air. These aerosols are generated either directly from fine respiratory droplets expelled from infected person or when any aerosol generating procedure is performed on an infected person. Aerosols thus refer to particles in suspension.

Figure 1 demonstrates the potential routes of COVID-19 transmission in the dental practice. $\mathrm{OHCW}$ can be exposed to COVID-19 via direct and indirect transmission pathways. Direct routes of transmission include exposure to droplets and aerosols generated during dental procedures. Indirect routes of transmission include the contact of the OHCW to contaminated surfaces in the dental practice as well as exposed auxiliary staff.

The classification COVID-19 as an infectious agent being "aerosol-transmissible" has significant implications for $\mathrm{OHCW}$ and the type of Personal Protective Equipment (PPE) that is required. ${ }^{5}$

Established routes of transmission of COVID-19 in humans includes direct transmission (through cough, sneeze, droplet inhalation) and contact transmission (contact via oral, nasal and eye mucous membranes). ${ }^{2}$ Evidence suggests that even non-symptomatic indivi- 


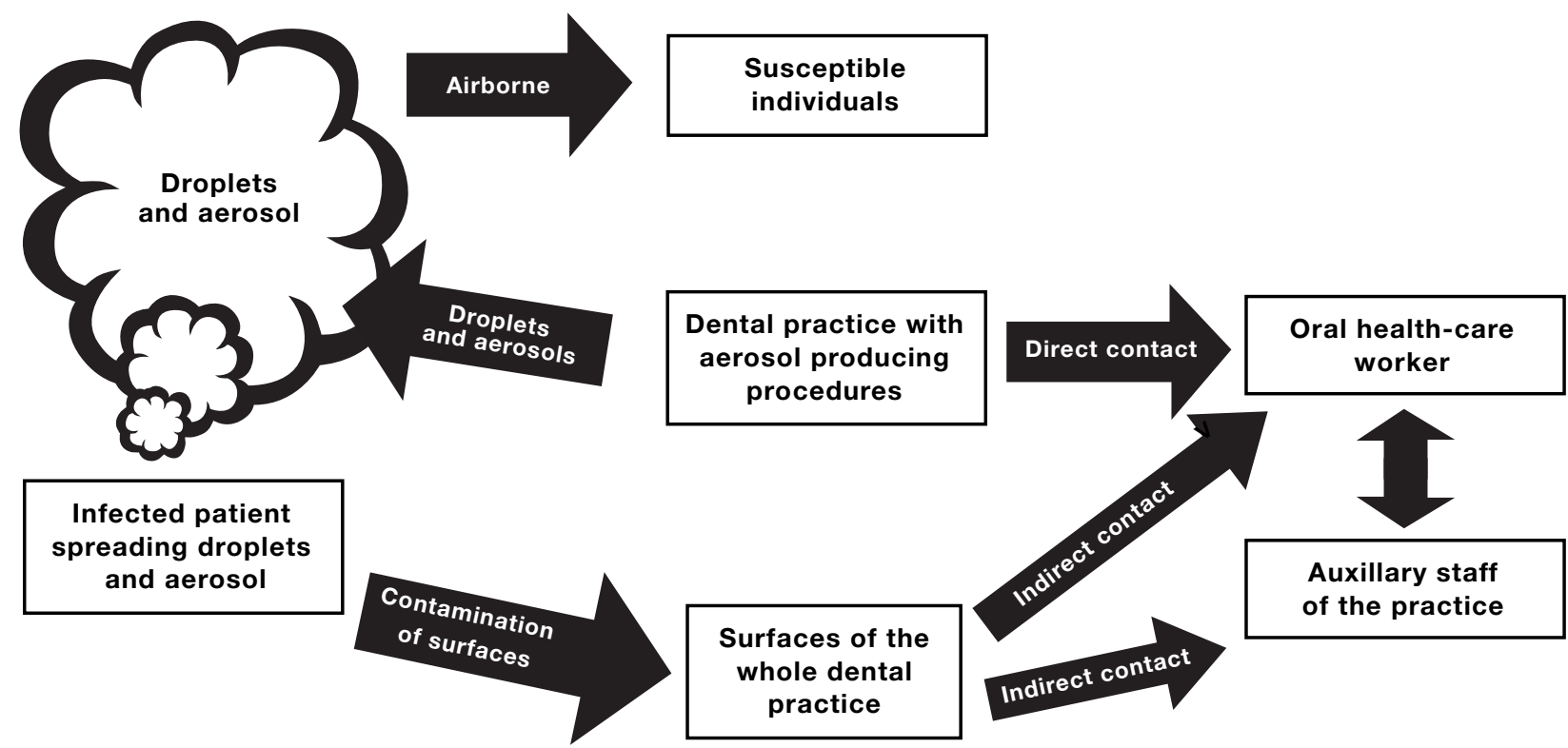

Figure 1. Adapted illustration of transmission routes of COVID-19 in the dental setting. ${ }^{3}$

duals can spread COVID-19 with high efficiency. Case studies from The Peoples Republic of China have also demonstrated that even after recovery from acute illness patients continued to shed high amounts of the virus. $^{3}$

Dental practices carry a very high risk of COVD-19 transmission due to close proximity of the oral cavity and face-to-face communication with patients. The procedures conducted in daily practice causes repeated exposure of the OHCW to aerosol, blood and saliva. ${ }^{2}$

Studies utilizing viral culture methods have shown that Covid-19 is present in saliva samples. ${ }^{6}$ Currently, ocular symptoms are not commonly associated with COVID-19 infection. However, analysis of conjunctival samples from confirmed cases of COVID-19, suggests that transmission is not limited to the respiratory tract and that eye exposure may be an effective pathway for the virus to enter the body. ${ }^{2}$

\section{MASKS AS PART OF DAILY PPE}

The utilization of the correct PPE is not only limited to the dental practitioner. The entire dental team should be equipped and trained in the use of the correct PPE and disinfection protocols. A survey under dental assistants from the Limpopo province reported that a mere $76.3 \%$ wore masks during dental procedures. ${ }^{?}$

For the OHCW the mask will become an essential PPE item of practice as COVID-19 continues to spread. The World Health Organisation (WHO), currently recommends that individuals who show signs of respiratory symptoms (cough and difficulty breathing) with fever, should wear a mask and seek medical attention. ${ }^{8}$

The world is contemplating as to whether all individuals wearing masks in public would help to flatten the curve of the spread. This is a growing concern as many countries are reportedly running out of facemasks and respirators.
Countries are adopting various strategies to drastically increase the production of this form of PPE. The question however remains: "Can a mask really protect you from catching the virus?" More importantly: "Are these masks protecting health care workers from contracting the dreaded COVID-19?" The answer to this question needs to contemplate the size of the COVID-19 virus and the level of determined filtration that masks and respirators currently offer.

It is important to note that not all masks and respirators products perform optimally in all clinical settings. Masks and respirators present only one component of PPE.

OHCW should correctly select and apply masks and respirators in the clinical environment. This require an in-depth knowledge and understanding of droplet and aerosol transmission, to place the COVID-19 pandemic into perspective.

\section{AEROSOLS AND DROPLETS IN DAILY LIFE}

Dental literature has demonstrated that many dental procedures produce aerosols and droplets that are contaminated with pathogenic micro-organisms, such as a bacteria and viruses. ${ }^{9}$

It is important to realise that all individuals are exposed to aerosols and droplet in daily life. Table 1 provides insight to understanding the implications of particle size of an aerosol and droplet, since particle sizes have significant implications for disease transmission..$^{4,5}$

Both droplets and aerosols are generated during coughing, sneezing, talking and even exhaling. ${ }^{4}$ Normal daily activities such as speaking and breathing have recorded predominant particle sizes of $1 \mu \mathrm{m}$, regardless of voice amplitude projected. ${ }^{12,13,14}$

The particles generated from coughing have a greater velocity and range between 0.57 to $0.89 \mu \mathrm{m}$ (average 
$0.63 \mu \mathrm{m}) .{ }^{15}$ Sneezing reportedly produces the largest droplet with an approximate particle size of $360.1 \mu \mathrm{m} .{ }^{16}$ Studies have demonstrated that $1 \mu \mathrm{m}$ particles have sufficient volume to transmit diseases from one person to another. Despite their small size, however, these micronscale particles are sufficiently large enough to carry a variety of respiratory pathogens such the measles virus $(0.05-0.5 \mu \mathrm{m})^{17}$, influenza virus $(0.1-1 \mu \mathrm{m})^{18}$ and Mycobacterium tuberculosis $(1-3 \mu \mathrm{m}) .^{19}$

Recent work by Yan et al. has confirmed that significant amounts of influenza viral RNA are present in small particles $(<5 \mu \mathrm{m})$ emitted by influenza-infected individuals during natural breathing, even without the infected individual coughing or sneezing. ${ }^{20}$

The risk of transmission with COVID-19 becomes apparent when the particle size ranging between 0.06 and $0.14 \mu \mathrm{m}$ is considered. ${ }^{21}$ Thus, COVID-19 can be considered as a 'small particle' microbe with a high potential risk of airborne transmission.

\begin{tabular}{|c|c|}
\hline Particle size & Implications for transmission \\
\hline \multirow{5}{*}{$\begin{array}{l}<5-10 \mu \mathrm{m} \\
\text { 'small particles' }\end{array}$} & This is aerosol and can be smaller than $5 \mu \mathrm{m}$ as well. \\
\hline & Aerodynamic diameter that follow airflow streamlines. \\
\hline & $\begin{array}{l}\text { Mainly short range transmission }{ }^{4} \text { and long range if } \\
\text { strong air currents present. }\end{array}$ \\
\hline & $\begin{array}{l}\text { Readily penetrates the airways all the way down to } \\
\text { the alveolar space (causing lower respiratory tract in- } \\
\text { fections LRT). }{ }^{4}\end{array}$ \\
\hline & High risk for airborne transmission. ${ }^{10,11}$ \\
\hline \multirow[t]{4}{*}{$\begin{array}{l}>20 \mu \mathrm{m} \\
\text { 'large particles' }\end{array}$} & $\begin{array}{l}\text { This splatter than can travel } 15-120 \mathrm{~cm} \text { from } \\
\text { the patient. }\end{array}$ \\
\hline & $\begin{array}{l}\text { Follow a more ballistic trajectory (i.e. falling mostly } \\
\text { under the influence of gravity - where the droplets are } \\
\text { too large to follow inhalation airflow streamlines. }\end{array}$ \\
\hline & $\begin{array}{l}\text { Most likely impact respiratory epithelial mucosa sur- } \\
\text { faces or trapped by cilia before reaching lower respi- } \\
\text { ratory tract (LRT). }\end{array}$ \\
\hline & $\begin{array}{l}\text { Associated with upper respiratory tract (URT) } \\
\text { infections. }{ }^{10,11}\end{array}$ \\
\hline
\end{tabular}

\section{AEROSOLS IN DENTISTRY}

In the dental practice, aerosols are produced by equipment such as ultrasonic scalers and fast hand pieces. Aerosolised water from dental equipment can range from aerosol to splatter $(0.001 \mu \mathrm{m}$ to $50 \mu \mathrm{m})$. Aerosols with particles greater than $100 \mu \mathrm{m}$, settle quickly to the floor and other surfaces. ${ }^{22}$ Aerosols become suspended in the air when the particle size is smaller than $50 \mu \mathrm{m}^{23}$

Dental lasers are included as an aerosol producing procedures due to the generation of the lasers plume. For lasers high-efficiency particulate filtration respirator to the efficiency of $99.75 \%$ at $0.1 \mu \mathrm{m}$ have been suggested. ${ }^{24}$ For dental lasers this would therefore be a respirator with a rating of N99, N100 or FFP3.

A Study evaluating the air quality in a dental setting with dental procedures such as extractions, air turbine with water spray and ultrasonic procedures, found that the micro-organism level in the dental surgery generally took 10-30 minutes to return to normal. This study also calculated that the practitioner and assistant was ex- posed to between $0.014 \mu \mathrm{l}$ to $0.12 \mu \mathrm{l}$ aerosolised saliva during a 15 minute peak exposure period.

Based on the results obtained, the study calculated that if a patient with Mycobacterium tuberculosis (M. tuberculosis) was treated, the practitioner could potentially have inhaled between 0.98 to 8.40 colony forming units (cfu) of M. tuberculosis, resulting in infection. Airborne M. tuberculosis is the main route of transmission generated by coughs and sneezes with droplet nuclei $1-5 \mu \mathrm{m}$ in size. ${ }^{25}$

Studies have shown that COVID-19 become airborne through aerosols and droplets, generated during medical and dental procedures. ${ }^{26}$ Dental practice generated droplets and aerosols from infected patients are likely to contaminate the whole surfaces in a dental practice. ${ }^{2}$

Studies investigating generated $5 \mu \mathrm{m}$ COVID-19 particles, reported that they remained viable for the duration of the 3 hour in vitro experiment. Further to this, COVID-19 was demonstrated to be the most stable when it remained on plastic and stainless steel surfaces, compared to copper and cardboard.

Although the COVID-19 virus reduced in virility over time, viable particles were present up to 72 hours after application to these surfaces. The half-live of aerosolised Covid-19 in the air had a virility of about 1.1 hours. ${ }^{26}$ The problem that therefore exists with COVID-19, is the ability to settle on surfaces within the practice, where it can survive for extended periods of time.

\section{REDUCTION OF AEROSOL}

In 1963 Miller et al. demonstrated that polishing cups, air turbines with water spray and polishing restorations with a bristle brush generated particles with various levels of microbial contamination. ${ }^{10}$

Besides the guidelines that the Centres for Disease Control and $\mathrm{WHO}$ will advise in due time, OHCW can start to reduce the microbial load in the oral cavities of patients with pre-procedural mouth rinses ${ }^{27}$, tooth brushing before the visit ${ }^{28}$ and high volume evacuation ${ }^{29}$ next to the aerosol generating equipment. ${ }^{30}$

According to "Guideline for Diagnosis and Treatment of Novel Coronavirus Pneumonia" (National Health Commission) chlorhexidine as a pre-procedural mouth rinse may not be effective to kill COVID-19. COVID-19 is vulnerable to oxidation, thus pre-procedural mouth rinses containing oxidative agents such as 1\% hydrogen peroxide or $0,2 \%$ povidone are recommended to reduce the salivary load of microbes (including COVID-19 carriage). ${ }^{2}$

Additionally, studies have also concluded that the use of rubber dams significantly reduce the contamination to the $\mathrm{OHCW}$ and the surrounding dental environment. ${ }^{31}$ Lastly disposable protective clothing and a protective face shield (as recommended by the CDC) additionally aid in the protection from splatter droplets, since droplets escape the high volume evacuation due to the air stream flowing from the dental equipment. ${ }^{32}$ 


\section{MASKS AND RESPIRATORS}

There are various masks and respirators available in the medical profession. Facial filtering protective equipment can be categorised into two broad categories, namely masks and respirators. They are fundamentally different in their intended use and the level of protection they provide.

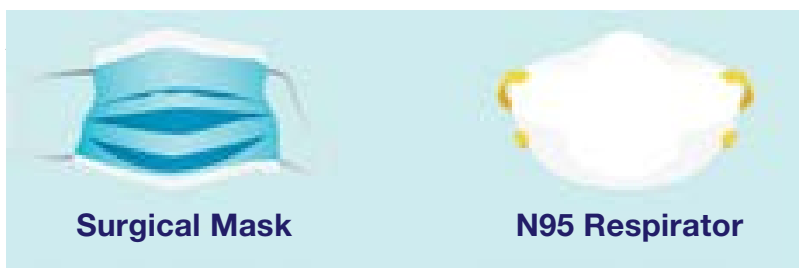

Figure 2. An example of a mask and respirator. ${ }^{33}$

Surgical masks (predominantly worn in theatre) have the primary purpose of preventing biological particles in droplet form infecting the health care practitioner. The expelled droplets and aerosol generated by the practitioner (by breathing, talking, sneezing etc.) is filtered to prevent contamination of the surgical environment. ${ }^{34}$ Surgical masks are also designed to be fluid-resistant to splash and splatter of blood and other bodily fluids during a procedure. A high quality surgical mask can filter mean particle sizes of $2.7 \mu \mathrm{m}$.

The limitation of surgical masks are that they are not necessarily designed to seal tightly to the face, thus air can potentially leak around the edges. Hence, they do not completely reduce the exposure to airborne particles. ${ }^{35}$

Respirators create an effective facial seal to cover the nose and mouth, aiding in preventing inhalation of hazardous airborne particles, gases and vapours. Respirators offer varying degrees of filtration, based on their classification.

Three key criteria are required for a respirator to be effective: ${ }^{36}$

1. The filter materials in the various layers used in the respirator needs to be extremely effective at capturing hazardous particles.

2. The respirator needs to fit snugly around the wearers face to create and maintain an effective facial seal. This seal minimises the amount of particles that are able to enter through gaps found between the skin and the respirator

3. The respirator needs to be put-on (don) and removed (doff) correctly.

Respirators have various descriptive criteria (letters) based on their resistance to oil. The letter in the name of the respirator rated as $\mathrm{N}, \mathrm{R}$ or $\mathrm{P}$. This rating is important in industry because some industrial oils can degrade the filter performance so it does not filter properly for that environment. Respirators are rated ' $N$ ', if they are Not resistant to oil, ' $R$ ' if somewhat Resistant to oil, and ' $P$ ' if strongly resistant (oil Proof).

The numerical value refers to the filtration capacity of the respirator. Therefore, a N95 respirator could also have ratings as $\mathrm{R95}$ or P95 based on the industry with the same level of filtration to particles. In terms of the recommended N95, the European equivalent is FFP2 and for N99 it is FFP3. ${ }^{36}$

Additionally, some more expensive respirators will be approved by the National Institute for Occupational Safety and Health (NIOSH) in the United States to have the characteristics of both a respirator and a surgical mask (i.e. fluid-resistant to splash, splatter of blood and other bodily fluids) for use in theatres.

The N95 respirator provides 8-12 times more protection, than a surgical mask with exposure to particles with a size between 0.04-1.3 $\mu \mathrm{m} .{ }^{37}$

National Institute for Occupational Safety and Health have produced valuable videos regarding PPE that can be viewed at the following online addresses:

https://www.cdc.gov/niosh/docs/video/default.html

\section{MANUFACTURE REGULATIONS PERTAINING TO MASKS}

Respirators are certified through the Centre of Disease Control (CDC) and the National Institute for Occupational Safety and Health (NIOSH) in the United States. All respirators in the United States need to comply with a complete respiratory program in accordance with the Occupational Safety and Health Administration (OSHA). ${ }^{36}$ Each country has a performance standards to which the respirators must be produced. In South Africa, the performance standard is approved by the South African Bureau of Standards (SABS) and the National Regulator for Compulsory Specifications (NRCS) under SANS 103 38: 2009. This is the equivalent performance standard from Europe EN149: 2001.

The Respiratory Protection Standards require all health care professionals to use respirators with tight fitting face pieces. Health care professionals also need to be adequately trained in the proper use, safe doffing and disposal of these respirators and can view various videos to educate them on donning and doffing:

https://www.cdc.gov/niosh/npptl/topics/respirators/disp _part/donningdoffing.html.

Health care professionals also need to be knowledgeable on the medical conditions that provide contraindications of using respirators. ${ }^{36}$ Heart conditions, lung disease and psychological conditions like claustrophobia could be contra-indications to those clinicians. In the United States, OSHA recommend the evaluation of the staff member by a medical practitioner with a medical questionnaire to evaluate the medical history and safety of the intended respirator for that practitioner. The questionnaire can be obtained at this link:

https://www.osha.gov/laws-regs/regulations/standard number/1910/1910.134AppC.

Furthermore, it is a requirement from OSHA that all healthcare workers are expected to perform all activities with suspected or confirmed cases of COVID-19 
wearing respiratory protection. A filtering face piece such as a N95 respirator is recommended as it seals the face covering the mouth and nose. It also has the ability to remove $95 \%$ of airborne particles from the users breathing air due to the built in filter. ${ }^{36}$

The CE marking and the performance standard of the respirator must be visible on the respirator, as well as on the packaging. Table 2 presents detail of the standard of testing, based on the various geographical locations where the respirators were manufactured.

The Food and Drug administration in the Unites States released Table 2 on 28 March 2020 of allowed respirators against the COVID-19 pandemic for importation to the United States.

\section{FACIAL FIT AND SEAL TESTING}

An adequately fitted respirator is of utmost importance to ensure there is no leakage around the edges of the respirator. The respirator needs to seal tightly and completely on the wearer's face. It is important to follow the user instructions and follow a user seal check before entering a contaminated or sterile environment. ${ }^{35}$

The seal of the respirator should be evaluated by feeling for exhaled air moving past the edges of the respirator. Any area where the seal is inadequate should be investigated for facial hair and materials/cloth that may interfere with the respirator making contact with the skin.

If the wearer is unable to shave then a Powered Air Purifying Respirator (PAPR) should be considered as an alternative. Some PAPR's are designed to fit under the wearers chin or at the neck making them a suitable alternative. $^{35}$

\section{DONNING A PPE RESPIRATOR ${ }^{38}$}

1. Ensure adequate hand hygiene or first layer of cloves.

2. Hold the respirator in the palm of your hand with the straps facing the floor.

3. Place the respirator on your face covering your nose and mouth.

4. Pull the bottom strap up and over top of your head, and put it behind your head below your ears.

5. Take the upper strap and put it behind your head towards the crown of your head.
6. Mould the nosepiece of the respirator over the bridge of your nose to obtain a tight seal.

7. Perform a fit check to ensure there is a good seal against the skin.

The video illustrating this procedure is available at:

https://www.cdc.gov/vhf/ebola/hcp/ppe-training/n95respirator_gown/donning_09.html

\section{RESPIRATORS WITH VALVES}

The main purpose of a respirator valve is to decrease breathing resistance during exhalation. This has no impact on the respirators ability to provide adequate respiratory protection to the $\mathrm{OHCW}$. The design of the valves allows exhaled air to exit during exhalation and to tightly close during inhalation, consequently preventing any inhaled air from entering the valve during inhalation.

Due to the nature of the valve - it should not be recommended to $\mathrm{OHCW}$, since exhaled particles exiting the respirator through the valve will contaminate the environment or sterile field in theatre. Thus, they are not recommended for OHCW, as they could become the nexus for local transmission.

\section{RE-USE OF RESPIRATORS}

In theory, the respirator can provide eight hours of respiratory filtration. The largest risk of cross-contamination from the respirator to the $\mathrm{OHCW}$ is during doffing of the respirator and then self-inoculation from surface droplets. Wearing an ear loop mask or face shield, over the respirator could protect the respirator from surface contamination. The only truly viable option to reduce the daily numbers of respirators is to don the respirator and keep it on for the duration of the clinical day, with ear loop mask replacement after every patient.

In this time of COVID-19 with a worldwide shortage of PPE, the extended use of respirators is frequent. A respirator manufacturer has conducted research on the sterilisation procedures for respirators and assessed their subsequent filtration capacity. The four main criteria for successful disinfection investigated included the following:

1). Be effective against the target organism (COVID-19).

2). Not damage the respirator's filtration.

3). Not affect the respirator's fit.

4). Be safe for the person wearing the respirator (e.g. no off-gassing of chemicals into the breathing zone).

\begin{tabular}{llll}
\hline $\begin{array}{l}\text { Table 2. COVID-19 respirators imported to United States. } \\
\text { Jurisdiction }\end{array}$ & Made to performance standard & Acceptable product classifications & Standards / Guidance documents \\
\hline Australia & AS/NZS 1716:2012 & P3, P2 & AS/NZS 1715:2009 \\
Brazil & ABNT/NBR 13698:2011 & PFF3, PFF2 & Fundacentro CDU 614.894 \\
Europe & EN 149-2001 & FFP3, FFP2 & EN 529:2005 \\
Japan & JMHLW-2000 & DS/DL3, DS/DL2 & JIS T8150: 2006 \\
Korea & KMOEL-2017-64 & Special 15t & KOSHA GUIDE H-82-2015 \\
USA / Canada & NIOSH / FDA Health Canada Licence & N95 surgical respirator & NIOSH approved \\
Mexico & NOM-116-2009 & N100, P100, R100, N99, P99, R99, N95, P95, R95 NOM-116 & N
\end{tabular}


The various disinfection methods assessed in this study included:

1). Ionizing radiation.

2). Ethylene oxide.

3). Ultraviolet germicidal irradiation (UVGI).

4). Microwave-generated stream (MGS).

5). Moist heat.

These disinfection methods did not completely meet the set out criteria, to be justified as successful. As of 27 March 2020, no disinfection method has met all four of these key criteria, and without all four, the method is not acceptable. $3 \mathrm{M}$ is now working with several major sterilization and disinfection companies and consulting with external experts to develop an effective disinfection method. $3 \mathrm{M}$ is working towards a solution to meet the abovementioned criteria. ${ }^{39}$

The CDC therefore have stated discarding recommendations for respirators, to prevent a significant risk for contact transmission, self-inoculation or reduced functionality 40:

1). Discard respirators following use during aerosol generating procedures.

2). Discard respirators contaminated with blood, respiratory or nasal secretions, or other bodily fluids from patients.

3). Discard respirators following close contact with any patient co-infected with an infectious disease requiring contact precautions in Table 2.

4). Consider the use of a cleansable face shield ${ }^{41}$ over a respirator and/or other steps (e.g. masking patients, use of engineering controls), when feasible to reduce surface contamination of the respirator.

5). Hang used non-contaminated respirators in a designated storage area or keep them in a clean, breathable container such as a paper bag between uses.

6). To minimize potential cross-contamination, store respirators so that they do not touch each other and the person using the respirator is clearly identified.

7). Storage containers should be disposed of or cleaned regularly.

8). Clean hands with soap and water or an alcoholbased hand sanitizer before and after touching or adjusting the respirator (if necessary for comfort or to maintain fit).

9). Avoid touching the inside of the respirator. If inadvertent contact occurs with the inside of the respirator, discard the respirator and perform hand hygiene as described above.

10). Use a pair of clean (non-sterile) gloves when donning a used respirator and performing a user seal check. Discard gloves after the respirator is donned and after any adjustments are made to ensure the respirator is creating an effective facial seal.

\section{WHO AND CDC ADVICE TO HEALTH CARE WORKERS}

The WHO and CDC have published a table of recommendations to curb the spread of COVID-19 in health care facilities. This table is continuously in flux and updates are available on the websites of the CDC and $\mathrm{WHO}$, as the COVID-19 pandemic is further studied and knowledge increases.

\section{CONCLUSION}

During daily dental procedures, aerosol production is often unavoidable. Due to the nature of the dental setting and current findings in the literature, it is the opinion of the authors that only N95/FFP 2 (or equivalent respirators) are recommended for $\mathrm{OHCW}$ during this COVID-19 pandemic.

OHCW additionally should take the steps outlined to minimise aerosol production and adhere to the current recommendations of disinfection protocols as set out by the CDC.

\section{Declaration}

The authors declare no conflict of interest.

\begin{tabular}{|c|c|c|}
\hline $\begin{array}{l}\text { Type of } \\
\text { precautions }\end{array}$ & Rationale & Measures \\
\hline \multirow[t]{6}{*}{ Standard } & \multirow{6}{*}{$\begin{array}{l}\text { To minimise the spread of in- } \\
\text { fection within healthcare fa- } \\
\text { cilities from direct contact of } \\
\text { contaminations }\end{array}$} & Practice hand hygiene \\
\hline & & Use of PPE \\
\hline & & Practice respiratory etiquette \\
\hline & & $\begin{array}{l}\text { Environmental cleaning } \\
\text { and disinfection }\end{array}$ \\
\hline & & $\begin{array}{l}\text { Proper handling of patient } \\
\text { care equipment and waste } \\
\text { management }\end{array}$ \\
\hline & & $\begin{array}{l}\text { Proper handling of needles and } \\
\text { other sharps }\end{array}$ \\
\hline \multirow[t]{4}{*}{ Contact } & \multirow{4}{*}{$\begin{array}{l}\text { To minimise the spread of in- } \\
\text { fections particularly by hand- } \\
\text { to-hand contact and self-in- } \\
\text { oculation of nasal and/or } \\
\text { conjunctival mucosa }\end{array}$} & $\begin{array}{l}\text { Proper use of PPE including } \\
\text { disposable gloves and gowns }\end{array}$ \\
\hline & & $\begin{array}{l}\text { Appropriate patient placement } \\
\text { in a single room or with patient } \\
\text { infected by some pathogen }\end{array}$ \\
\hline & & $\begin{array}{l}\text { Limit patient movement and mi- } \\
\text { nimise patient contact }\end{array}$ \\
\hline & & $\begin{array}{l}\text { Environmental cleaning and } \\
\text { disinfection of the patient room }\end{array}$ \\
\hline \multirow[t]{3}{*}{ Droplet } & \multirow{3}{*}{$\begin{array}{l}\text { To minimise the spread of re- } \\
\text { spiratory infections that are } \\
\text { transmitted predominantly via } \\
\text { large droplets }(>5 \mu \mathrm{m}) \text { in short } \\
\text { distance }\end{array}$} & $\begin{array}{l}\text { Proper use of PPE including } \\
\text { surgical mask when entering } \\
\text { the patient's room }\end{array}$ \\
\hline & & $\begin{array}{l}\text { Appropriate patient placement } \\
\text { in a single room or with patient } \\
\text { infected by same pathogen. }\end{array}$ \\
\hline & & $\begin{array}{l}\text { Limit patient movement and } \\
\text { ensure that patients wear sur- } \\
\text { gical mask when outside their } \\
\text { rooms. }\end{array}$ \\
\hline \multirow[t]{3}{*}{ Airborne } & \multirow{3}{*}{$\begin{array}{l}\text { To minimise the spread of } \\
\text { respiratory infections that are } \\
\text { transmitted through inhalation } \\
\text { of infectious aerosols }(\leq 5 \mu \mathrm{m}) \\
\text { over a long distance }\end{array}$} & $\begin{array}{l}\text { Proper use of PPE including } \\
\text { N95/FFP2 or equivalent partic- } \\
\text { ulate respirator. }\end{array}$ \\
\hline & & $\begin{array}{l}\text { Isolation of patient in single, } \\
\text { airborne isolation infection } \\
\text { room (AllR). }\end{array}$ \\
\hline & & $\begin{array}{l}\text { Limit patient movement and en- } \\
\text { sure that patients wear surgical } \\
\text { mask when outside their rooms. }\end{array}$ \\
\hline
\end{tabular}




\begin{tabular}{|c|c|c|c|c|c|c|c|c|}
\hline \multirow[t]{2}{*}{ Category } & \multirow[t]{2}{*}{ Cloth masks } & \multirow{2}{*}{\multicolumn{2}{|c|}{ Surgical masks }} & \multicolumn{5}{|c|}{ N95 (3M) } \\
\hline & & & & \multicolumn{2}{|c|}{ Model 1860 S } & \multicolumn{2}{|l|}{ Model 1870+ } & VFlex \\
\hline $\begin{array}{l}\text { Can be used as } \\
\text { a medical device }\end{array}$ & No & \multicolumn{2}{|l|}{ Yes } & \multicolumn{2}{|l|}{ Yes } & \multicolumn{2}{|l|}{ Yes } & Yes \\
\hline Filter efficiency & $\begin{array}{l}\text { Currently no published } \\
\text { research available on } \\
\text { efficacy of cloth masks. }\end{array}$ & \multicolumn{2}{|c|}{$\begin{array}{l}\text { Does not provide the wearer } \\
\text { with a protection from inhala- } \\
\text { tion of small airborne particles. } \\
\text { Not considered respiratory pro- } \\
\text { tection. }\end{array}$} & \multicolumn{2}{|c|}{$\begin{array}{l}\geq 95 \% \text { of airborne particles } \\
\text { (Both large and small). }\end{array}$} & \multicolumn{2}{|c|}{$\begin{array}{l}\geq 95 \% \text { of airborne particles } \\
\text { (Both large and small). }\end{array}$} & $\begin{array}{l}\geq 95 \% \text { of airborne particles } \\
\text { (Both large and small). }\end{array}$ \\
\hline Purpose & & \multicolumn{2}{|c|}{$\begin{array}{l}\text { Used to block large particles/ } \\
\text { droplets that may contain } \\
\text { micro-organisms. } \\
\text { Protects the patient from the } \\
\text { wearer's respiratory emissions. }\end{array}$} & \multicolumn{2}{|c|}{$\begin{array}{l}\text { Reduces the wearers } \\
\text { exposure to large droplets/ } \\
\text { particles and smaller } \\
\text { particle aerosols. }\end{array}$} & \multicolumn{2}{|c|}{$\begin{array}{l}\text { Reduces the wearers ex- } \\
\text { posure to large droplets/ } \\
\text { particles and smaller par- } \\
\text { ticle aerosols. }\end{array}$} & $\begin{array}{l}\text { Reduces the wearers } \\
\text { exposure to large droplets/ } \\
\text { particles and smaller } \\
\text { particle aerosols. }\end{array}$ \\
\hline Face seal fit & Loose/ill-fitting. & \multicolumn{2}{|c|}{ Loose fitting. } & \multicolumn{2}{|c|}{$\begin{array}{l}\text { Tight fitting, seals over } \\
\text { mouth and nose }\end{array}$} & \multicolumn{2}{|c|}{$\begin{array}{l}\text { Tight fitting, seals over } \\
\text { mouth and nose. }\end{array}$} & $\begin{array}{l}\text { Tight fitting, seals over } \\
\text { mouth and nose. }\end{array}$ \\
\hline $\begin{array}{l}\text { User seal check } \\
\text { requirement }\end{array}$ & No. & \multicolumn{2}{|l|}{ No. } & \multicolumn{2}{|c|}{$\begin{array}{l}\text { Yes - required every time } \\
\text { its put on. }\end{array}$} & \multicolumn{2}{|c|}{$\begin{array}{l}\text { Yes - required every time } \\
\text { its put on. }\end{array}$} & $\begin{array}{l}\text { Yes - required every time } \\
\text { its put on. }\end{array}$ \\
\hline Leakage & $\begin{array}{l}\text { Leakage can occur } \\
\text { through the fabric and } \\
\text { around the edges of } \\
\text { the mask. }\end{array}$ & \multicolumn{2}{|c|}{$\begin{array}{l}\text { Leakage occurs around the } \\
\text { edges of the mask between the } \\
\text { face and mask. }\end{array}$} & \multicolumn{2}{|c|}{$\begin{array}{l}\text { When correctly put on and } \\
\text { fitted - minimal leakage } \\
\text { occurs. }\end{array}$} & \multicolumn{2}{|c|}{$\begin{array}{l}\text { When correctly put on and } \\
\text { fitted - minimal leakage } \\
\text { occurs. }\end{array}$} & $\begin{array}{l}\text { When correctly put on and } \\
\text { fitted - minimal leakage } \\
\text { occurs. }\end{array}$ \\
\hline Fluid resistance & Not fluid resistant & \multicolumn{2}{|c|}{$0.04 \mu \mathrm{m}-1.3 \mu \mathrm{m}$} & \multicolumn{2}{|c|}{$\begin{array}{l}\text { Splashes at } 120 \mathrm{~mm} \mathrm{Hg} \text {. } \\
\text { Not resistant to oil }\end{array}$} & \multicolumn{2}{|c|}{$\begin{array}{l}\text { Splashes at } 160 \mathrm{~mm} \mathrm{Hg} \text {. } \\
\text { Not resistant to oil. }\end{array}$} & $\begin{array}{l}\text { Splashes at } 80 \mathrm{~mm} \mathrm{Hg} \text {. } \\
\text { Not resistant to oil. }\end{array}$ \\
\hline Valve/no valve & No & \multicolumn{2}{|l|}{ No } & \multicolumn{2}{|l|}{ No valve } & \multicolumn{2}{|l|}{ No valve } & No valve \\
\hline Use limitation & $\begin{array}{l}\text { Non-surgical/medical. } \\
\text { Needs to be washed } \\
\text { frequently. }\end{array}$ & \multicolumn{2}{|c|}{$\begin{array}{l}\text { Disposable. } \\
\text { Discard after each patient en- } \\
\text { counter. }\end{array}$} & \multicolumn{2}{|c|}{$\begin{array}{l}\text { Should ideally be discar- } \\
\text { ded after each patient or } \\
\text { after an aerosol producing } \\
\text { procedure. } \\
\text { Discarded if damaged or } \\
\text { deformed or the seal is } \\
\text { defective. } \\
\text { Should be discarded if } \\
\text { it becomes contaminated } \\
\text { with blood or other bodily } \\
\text { fluids from patients. }\end{array}$} & \multicolumn{2}{|c|}{$\begin{array}{l}\text { Should ideally be discar- } \\
\text { ded after each patient or } \\
\text { after an aerosol producing } \\
\text { procedure. } \\
\text { Discarded if damaged or } \\
\text { deformed or the seal is } \\
\text { defective. } \\
\text { Should be discarded if } \\
\text { it becomes contaminated } \\
\text { with blood or other bodily } \\
\text { fluids from patients. }\end{array}$} & $\begin{array}{l}\text { Should ideally be discar- } \\
\text { ded after each patient or } \\
\text { after an aerosol producing } \\
\text { procedure. } \\
\text { Discarded if damaged or } \\
\text { deformed or the seal is } \\
\text { defective. } \\
\text { Should be discarded if } \\
\text { it becomes contaminated } \\
\text { with blood or other bodily } \\
\text { fluids from patients. }\end{array}$ \\
\hline Category & \multicolumn{2}{|l|}{ N99 } & N100 & & & =FP2 & & FFP3 \\
\hline $\begin{array}{l}\text { Can be used as } \\
\text { a medical device }\end{array}$ & Yes & & Yes & & Yes & & Yes & \\
\hline Filter efficiency & $\begin{array}{l}\geq 99 \% \text { of airborne particles } \\
\text { (Both large and small). }\end{array}$ & & $\begin{array}{l}\geq 99.97 \% \text { of airborne par } \\
\text { (Both large and small). }\end{array}$ & & $\begin{array}{l}\geq 94 \% \text { of airborr } \\
\text { (Both large and }\end{array}$ & $\begin{array}{l}\text { ne particles } \\
\text { small). }\end{array}$ & $\begin{array}{l}\geq 99 \% \mathrm{C} \\
\text { (Both la }\end{array}$ & $\begin{array}{l}\text { of airborne particles } \\
\text { arge and small). }\end{array}$ \\
\hline Purpose & $\begin{array}{l}\text { Reduces the wearers exp } \\
\text { large droplets/particles an } \\
\text { particle aerosols. }\end{array}$ & $\begin{array}{l}\text { sure to } \\
\text { smaller }\end{array}$ & $\begin{array}{l}\text { Reduces the wearers ex } \\
\text { large droplets/particles } \\
\text { particle aerosols. }\end{array}$ & $\begin{array}{l}\text { posure to } \\
\text { and smaller }\end{array}$ & $\begin{array}{l}\text { Reduces the } w \\
\text { large droplets } / p \\
\text { particle aerosol }\end{array}$ & $\begin{array}{l}\text { earers exposure to } \\
\text { sarticles and smaller } \\
\text { s. }\end{array}$ & $\begin{array}{l}\text { Reduce } \\
\text { large dr } \\
\text { particle }\end{array}$ & $\begin{array}{l}\text { es the wearers exposure to } \\
\text { roplets/particles and smaller } \\
\text { aerosols. }\end{array}$ \\
\hline Face seal fit & $\begin{array}{l}\text { Tight fitting, seals over mo } \\
\text { and nose. }\end{array}$ & & $\begin{array}{l}\text { Tight fitting, seals over } n \\
\text { and nose. }\end{array}$ & nouth & $\begin{array}{l}\text { Tight fitting, sea } \\
\text { and nose. }\end{array}$ & als over mouth & $\begin{array}{l}\text { Tight fit } \\
\text { and no }\end{array}$ & $\begin{array}{l}\text { tting, seals over mouth } \\
\text { se. }\end{array}$ \\
\hline $\begin{array}{l}\text { User seal check } \\
\text { equirement }\end{array}$ & Yes - required every time & put on & Yes - required every tim & its put on & Yes - required e & every time its put on & Yes - re & equired every time its put on \\
\hline Leakage & $\begin{array}{l}\text { Minimal leakage occurs } \\
\text { rectly put on and fitted. }\end{array}$ & en cor- & $\begin{array}{l}\text { Minimal leakage occurs } \\
\text { rectly put on and fitted. }\end{array}$ & when cor- & $\begin{array}{l}\text { Minimal leakag } \\
\text { rectly put on an }\end{array}$ & $\begin{array}{l}\text { e occurs when cor- } \\
\text { d fitted. }\end{array}$ & $\begin{array}{l}\text { Minima } \\
\text { rectly } p\end{array}$ & $\begin{array}{l}\text { al leakage occurs when cor- } \\
\text { out on and fitted. }\end{array}$ \\
\hline Fluid Resistance & Not resistant to oil & & Not resistant to oil & & Strongly resista & nt to oil & Strongl & ly resistant to oil \\
\hline Valve/No Valve & No valve & & No valve & & Could be valvec & & Could $b$ & be valved \\
\hline Use limitation & $\begin{array}{l}\text { Should ideally be discarc } \\
\text { each patient or after an } \\
\text { producing procedure. } \\
\text { Discarded if damaged or } \\
\text { or the seal is defective. } \\
\text { Should be discarded if it } \\
\text { contaminated with blood } \\
\text { bodily fluids from patients. }\end{array}$ & $\begin{array}{l}\text { ed after } \\
\text { aerosol } \\
\text { eformed } \\
\text { ecomes } \\
\text { or other }\end{array}$ & $\begin{array}{l}\text { Should ideally be disc } \\
\text { each patient or after } \\
\text { producing procedure. } \\
\text { Discarded if damaged o } \\
\text { or the seal is defective. } \\
\text { Should be discarded if } \\
\text { contaminated with bloc } \\
\text { bodily fluids from patien }\end{array}$ & $\begin{array}{l}\text { arded after } \\
\text { an aerosol } \\
\text { deformed } \\
\text { it becomes } \\
\text { d or other } \\
\text { ts. }\end{array}$ & $\begin{array}{l}\text { Should ideally } \\
\text { each patient o } \\
\text { producing proc } \\
\text { Discarded if dar } \\
\text { or the seal is de } \\
\text { Should be disc } \\
\text { contaminated } \\
\text { bodily fluids fro }\end{array}$ & $\begin{array}{l}\text { be discarded after } \\
\text { r after an aerosol } \\
\text { edure. } \\
\text { maged or deformed } \\
\text { fective. } \\
\text { arded if it becomes } \\
\text { with blood or other } \\
\mathrm{m} \text { patients. }\end{array}$ & $\begin{array}{l}\text { Should } \\
\text { each } p \\
\text { produc } \\
\text { Discaro } \\
\text { or the s } \\
\text { Should } \\
\text { contam } \\
\text { bodily } f\end{array}$ & $\begin{array}{l}\text { ideally be discarded after } \\
\text { oatient or after an aerosol } \\
\text { ing procedure. } \\
\text { ded if damaged or deformed } \\
\text { seal is defective. } \\
\text { be discarded if it becomes } \\
\text { inated with blood or other } \\
\text { fluids from patients. }\end{array}$ \\
\hline
\end{tabular}

\section{References}

1. Kampf G, Todt D, Pfaender S, Steinmann E. Persistence of coronaviruses on inanimate surfaces and their inactivation with biocidal agents. J Hosp Infect. 2020; 104(3): 246-51. Available from: https://doi.org/10.1016/j.jhin.2020.01.022.

2. Peng $X, X u X, L i ~ Y$, Cheng L, Zhou X, Ren B. Transmission routes of $2019-n C o V$ and controls in dental practice. Inter J Oral Sci. 2020; 12(1): 1-6. Available from: http://dx.doi. org/10.1038/s41368-020-0075-9.

3. Chang D, Mo G, Yuan X, Tao Y, Peng X, Wang F, et al. Time Kinetics of Viral Clearance and Resolution of Symptoms in Novel Coronavirus Infection. American J Resp Crit Care Med. 2020 Mar 23; 1-12. Available from: https://www.atsjournals. org/doi/10.1164/rccm.202003-0524LE.
4. Shiu E, Leung N, Cowling B. Controversy around airborne versus droplet transmission of respiratory viruses: implication for infection prevention. Curr Opin Infect Dis. 2019; 32(4): 372-9.

5. Tellier R, Li Y, Cowling BJ, Tang JW. Recognition of aerosol transmission of infectious agents: a commentary. BMC Infect Dis. 2019; 19(101): 1-9.

6. To KK-W, Tsang OT-Y, Yip CC-Y, Chan K-H, Wu T-C, Chan $\mathrm{JM}-\mathrm{C}$, et al. Consistent Detection of 2019 Novel Coronavirus in Saliva. Clin Infect Dis. 2020 Feb 12; Available from: https://doi.org/10.1093/cid/ciaa149.

7. Nemutandani M, Yengopal V, Rudolph M, Tsotsi N. Occupational exposure among dental assistants in public health care facilities, Limpopo Province. SADJ. 2007; 62(8): 348-55. 
8. World Health Organization. Advice on the use of masks in the community, during home care and in healthcare settings in the context of the novel coronavirus (2019-nCoV) outbreak. Vol. Interim gu, Who. 2020; 1-2. Available from: https://www. who.int/docs/default-source/documents/advice-on-the-useof-masks-2019-ncov.pdf

9. Wei J, Li Y. Airborne spread of infectious agents in the indoor environment. Am J Infec Control. 2016; 44(9): S102-8. Available from: http://dx.doi.org/10.1016/j.ajic.2016.06.003.

10. Miller RL, Micik RE, Abel C, Ryge G. Studies on Dental Aerobiology: II. Microbial Splatter Discharged from the Oral Cavity of Dental Patients. J Dent Res. 1971; 50(3): 621-5.

11. Harrel S. Airborne spread of disease - implication for dentistry. J Calif Dent Assoc. 2004; 32(11): 901-6.

12. Edwards DA, Man JC, Brand P, Katstra JP, Sommerer K, Stone HA, et al. Inhaling to mitigate exhaled bioaerosols. Proc Natl Acad Sci USA. 2004; 101(50): 17383-8.

13. Fabian P, McDevitt JJ, DeHaan WH, Fung ROP, Cowling BJ, Chan $\mathrm{KH}$, et al. Influenza virus in human exhaled breath: An observational study. PLoS ONE. 2008; 3(7): 5-10.

14. Papineni RS, Rosenthal FS. The size distribution of droplets in the exhaled breath of healthy human subjects. J Aerosol Med. 2009; 10(2): 105-16.

15. Lindsley WG, Pearce TA, Hudnall JB, Davis KA, Stephen M, Fisher MA, et al. Quantity and Size Distribution of CoughGenerated Aerosol Particles Produced by Influenza Patients During and After Illness. J Occup Environ Hyg. 2012; 9(7): 443-9.

16. Han ZY, Weng WG, Huang QY. Characterizations of particle size distribution of the droplets exhaled by sneeze. J Royal Soc Interface. 2013; 10(88).

17. Liljeroos L, Huiskonen JT, Ora A, Susi P, Butcher SJ. Electron cryotomography of measles virus reveals how matrix protein coats the ribonucleocapsid within intact virions. Proc Natl Acad Sci USA. 2011; 108(44): 18085-90.

18. Rossman JS, Lamb RA. Influenza virus assembly and budding. Virol. 2011; 411(2): 229-36.

19. Fennelly KP, Jones-López EC, Ayakaka I, Kim S, Menyha H, Kirenga $\mathrm{B}$, et al. Variability of Infectious Aerosols Produced during Coughing by Patients with Pulmonary Tuberculosis. Am J Resp Critical Care Med. 2012; 186(5): 450-7.

20. Yan J, Grantham M, Pantelic J, De Mesquita PJB, Albert B, Liu F, et al. Infectious virus in exhaled breath of symptomatic seasonal influenza cases from a college community. Proc Natl Acad Sci USA. 2018; 115(5): 1081-6.

21. Cascella M, Rajnik M, Cuomo A, Dulebohn SC, Di Napoli R. Features, Evaluation and Treatment Coronavirus (COVID-19). StatPearls. 2020. Available from: http://www.ncbi.nlm.nih.gov/ pubmed/32150360.

22. Singh TS, Mabe OD. Occupational exposure to endotoxin from contaminated dental unit waterlines. SADJ. 2009; 64(1).

23. Veena HR, Mahantesha S, Joseph PA, Patil SR, Patil SH. Dissemination of aerosol and splatter during ultrasonic scaling: A pilot study. J Infect Public Heal. 2015; 8(3): 260-5. Available from: http://dx.doi.org/10.1016/j.jph.2014.11.004.

24. Convissar R. Principles and Practice of Laser Dentistry. $2^{\text {nd }}$ ed. Principles and Practice of Laser Dentistry. Elsevier; 2015. 1-328.

25. Wells W. Aerodynamics of droplet nuclei. Cambridge, MA: Harvard University Press; 1955. 13-19. Available from: https:// www.cabdirect.org/cabdirect/abstract/19562701497.

26. Van Doremalen N, Bushmake T, Morris DH, Holbrook MG, Gamble A, Williamson BN. Aerosol and Surface Stability of SARS-CoV-2 as Compared with SARS-CoV-1. N Engl J Med. 2020; 1-3.

27. Mohammed C, Manhold JH, Manhold B. Efficacy of Preoperative Oral Rinsing To Reduce Air Contamination During Use of Air Turbine Handpieces. JADA. 1964; 69(6): 715-8.
28. Wyler D, Miller RL, Micik RE. Efficacy of Self-Administered Preoperative Oral Hygiene Procedures in Reducing the Concentration of Bacteria in Aerosols Generated During Dental Procedures. J Dent Res. 1971; 50(2): 509.

29. Micik RE, Miller RL, Mazzarella MA, Ryge G. Studies on Dental Aerobiology: I. Bacterial Aerosols Generated during Dental Procedures. J Dent Re. 1969; 48(1): 49-56.

30. Timmerman MF, Menso L, Steinfort J, Van Winkelhoff AJ, Van Der Weijden GA. Atmospheric contamination during ultrasonic scaling. J Clinic Periodont. 2004; 31(6): 458-62.

31. Cochran MA, Miller CH, Sheldrake MA. The efficacy of the rubber dam as a barrier to the spread of microorganisms during dental treatment. JADA. 1989; 119(1): 141-4. Available from: http://dx.doi.org/10.14219/jada.archive.1989.0131.

32. Prospero E, Savini S. Microbial Aerosol Contamination of Dental Healthcare Workers' Faces and Other Surfaces in Dental Practice. Chic J. 2013; 24(2): 139-41. Available from: http://www.jstor.org/stable/10.1086/502172 .

33. CDC. Understanding the Difference. CDC. 2020. Available from:https://www.cdc.gov/niosh/nppt//pdfs. UnderstandingDifference3-508.pdf.

34. Bulletin T, Time W. Respirators and Surgical Masks: A Comparison. 2020; 2-5.

35. Division 3M Personal Safety. Respiratory Protection FAQ: Healthcare. Vol. 3, Bulletin, Technical. 2020.

36. Alessandro D, Maryann M. Proper N95 Respirator Use for Respiratory Protection Preparedness. CDC. 2020. Available from: https://blogs.cdc.gov/niosh-science-blog/2020/03/16/ n95-preparedness/.

37. Lee SA, Grinshpun SA, Reponen T. Respiratory performance offered by N95 respirators and surgical masks: Human subject evaluation with $\mathrm{NaCl}$ aerosol representing bacterial and viral particle size range. Ann Occup Hyg. 2008; 52(3): 177-85.

38. CDC, NCEZID, DHCP. Donning PPE : Put on N95 Respirator. CDC Website. 2014. Available from: https://www.cdc.gov/vhf/ ebola/hcp/ppe-training/n95respirator_gown/donning_09.html

39. 3M Scientific Division. Disinfection and of Filtering Facepiece Respirators. Technical Bulletin. 2020. Available from: http:// project-manus.mit.edu/wp-content/uploads/2020/03/Disinfection-of-3M_-Filtering-Facepiece-Respirators.pdf.

40. NIOSH, CDC. Recommended Guidance for Extended Use and Limited Reuse of N95 Filtering Facepiece Respirators in Healthcare Settings. 2020. Available from: https://www. cdc.gov/niosh/topics/hcwcontrols/recommendedguidance extuse.html.

41. Hines L, Rees E, Pavelchak N. Respiratory protection policies and practices among the health care workforce exposed to influenza in New York State: Evaluating emergency preparedness for the next pandemic. Am J Infect Control. 2014; 42(3): 240-5. Available from: http://dx.doi.org/10.1016/j.ajic. 2013.09.013.

42. CDC, WHO. Transmission-Based Precautions. CDC Website. 2016. Available from: https://www.cdc.gov/infectioncontrol/basics/transmission-based-precautions.html. 